\title{
Purification and Properties of a Fructooligosaccharide-producing $\beta$-Fructofuranosidase from Aspergillus niger ATCC 20611
}

\author{
Masao Hirayama, Naomi Sumi and Hidemasa Hidaka \\ Bio Science Laboratories, Meiji Seika Kaisha, Ltd., \\ 580, Horikawa-cho, Saiwai-ku, Kawasaki-shi, \\ Kanagawa 210, Japan
}

Received September 5, 1988

\begin{abstract}
A fructooligosaccharide-producing $\beta$-fructofuranosidase was purified from cells of Aspergillus niger ATCC 20611. The molecular weight was 340,000 by gel filtration. The optimum pH of the enzyme was $5.0 \sim 6.0$ and the optimum temperature was $50 \sim 60^{\circ} \mathrm{C}$. The enzyme was rendered inactive by $1 \mathrm{~m} \mathrm{M} \mathrm{Hg}{ }^{2+}$ and the $K m$ value for sucrose was $0.29 \mathrm{M}$. The enzyme catalyzed an almost exclusively fructosyl transfer reaction in a $\mathbf{5 0 \%}$ sucrose solution to produce a mixture of fructooligosaccharides and glucose, but both fructosyl transfer and hydrolytic action were observed in a $0.5 \%$ solution. The $\beta$ fructofuranosidase showed a high regiospecificity to transfer the fructosyl moiety for the 1-OH group of terminal fructofuranosides.
\end{abstract}

In a previous paper, ${ }^{1)}$ we reported fructooligosaccharide production by enzymic fructosyl transfer on sucrose, and Aspergillus niger ATCC 20611 was selected as the most suitable strain for the production. This strain showed a very high enzyme productivity and its transfructosylating activity was very strong compared to its hydrolyzing activity. The transfructosylating reaction proceeded smoothly even in a $50 \%(\mathrm{w} / \mathrm{v})$ solution of sucrose to give a mixture of fructooligosaccharides with an inulin-type structure of $1^{\mathrm{F}}$ - $(1-\beta$-fructofuranosyl $)_{n}$ sucrose $(n=1 \sim 3)$. This crude enzyme is of particular interest since it appears to be a $\beta$ fructofuranosidase which has a high transfructosylating activity and a high regiospecificity for fructosyl transfer to the 1-OH group of terminal fructofuranosides. ${ }^{1)}$ This paper describes the purification and properties of the fructooligosaccharide-producing enzyme from A. niger ATCC 20611.

\section{Materials and Methods}

Materials. DEAE-Sephadex A-50, Sepharose 6B and Sephadex G-200 were obtained from Pharmacia. 1Kestose $\left(\mathrm{GF}_{2}\right)$, nystose $\left(\mathrm{GF}_{3}\right)$ and $1^{\mathrm{F}}$-fructofuranosylnystose $\left(\mathrm{GF}_{4}\right)$ were purified from a mixture of fructo- oligosaccharides as described in a previous paper. ${ }^{11}$ Inulobiose $\left(\mathrm{F}_{2}\right)$ and inulotriose $\left(\mathrm{F}_{3}\right)$ were obtained by a modification of the method of Dickerson and Moor ${ }^{2)}$ The other saccharides, chemicals and standard proteins were purchased from commercial sources.

Cultivation conditions. A. niger ATCC 20611 was cultured at $28^{\circ} \mathrm{C}$ in a $30-1$ jar fermentor (Marubishi, Type MSJ-302) under aerated conditions (201/min). The cultivation medium (201) contained $5.0 \%$ sucrose, $0.7 \%$ maltoextract, $1.0 \%$ polypepton, $0.5 \%$ carboxymethyl-cellulose (CMC) and $0.3 \% \mathrm{NaCl}$. A subculture $(400 \mathrm{ml})$ grown under similar conditions as described in a previous paper ${ }^{1}$ was inoculated. After cultivation for $72 \mathrm{hr}$, the remaining culture medium was centrifuged at $4^{\circ} \mathrm{C}$ to obtain the cells $(2800 \mathrm{~g})$ and the supernatant solution $(20 \mathrm{l})$. The transfructosylating activities were $1.6 \mathrm{U}$ per $\mathrm{mg}$ for the cells and $0.13 \mathrm{U}$ per $\mathrm{ml}$ for the solution.

Cell-free crude enzyme. The wet cells $\left(880 \mathrm{~g}, 141 \times 10^{4} \mathrm{U}\right)$ were alternately frozen $\left(-20^{\circ} \mathrm{C}\right)$ and thawed $\left(20^{\circ} \mathrm{C}\right)$ three times, and the resulting material was sonicated (sonifier cell disruptor, model 350 ) on ice for $5 \mathrm{~min}$ in $10 \mathrm{~mm}$ Mcllvaine buffer $(4.01)$; $\mathrm{pH} 5.0$. The sonicated material was centrifuged and the supernatant $\left(4.461,4.84 \times 10^{5} \mathrm{U}\right)$ thus obtained was used as a crude extract.

\section{Analytical methods}

Enzyme assay. The enzyme activity was assayed as a trans-fructosylating activity by our previous methods. ${ }^{11}$ One units was defined as the amount of enzyme required to produce $1 \mu \mathrm{mol}$ of kestose per min from $10 \%(\mathrm{w} / \mathrm{v})$ 
sucrose at $40^{\circ} \mathrm{C}$ in $40 \mathrm{~mm}$ Mcllvaine buffer, $\mathrm{pH} 5.0$.

Protein estimation. Protein was measured by the method of Lowry et al., ${ }^{3)}$. using bovine serum albumin as the standard. Absorbance at $280 \mathrm{~nm}$ was used for monitoring protein in column eluates.

Carbohydrate estimation. The carbohydrate in the enzyme was estimated by the phenol-sulfuric acid method ${ }^{4)}$ using D-glucose as the standard. High performance liquid chromatography (HPLC) and thin-layer chromatography (TLC) analysis were done as described in a previous paper. ${ }^{11}$

Polyacrylamide gel electrophoresis. SDS-Polyacrylamide gel electrophoresis (SDS-PAGE) was done using a Phast system (Pharmacia) with a PhastGel Gradient $8 \sim 25$ (Pharmacia). Samples containing $1 \mathrm{~mm}$ EDTA, 2.5\% SDS, $5 \% 2$-mercaptoethanol, $10 \mathrm{~mm}$ Tris-HCl buffer, $\mathrm{pH} 8.0$, and $0.1 \%$ protein were left for $5 \mathrm{~min}$ in boiling water. After separation, proteins were stained with PhastGel Blue $\mathrm{R}$ (Coomassie Brilliant Blue).

Chromatofocusing chromatography. A column of polybuffer exchanger 94 (Mono P HR5/20, Pharmacia) was equilibrated with $25 \mathrm{~mm}$ imidazole buffer, $\mathrm{pH} 7.4$. The purified enzyme ( $800 \mu \mathrm{g}$ of protein) was put on the column and eluted with polybuffer 74 adjusted to $\mathrm{pH} 3.0$ by hydrochloric acid. The eluent was collected in $2-\mathrm{ml}$ fractions at a flow rate of $40 \mathrm{ml}$ per hr.

Estimation of the molecular weight by gel filtration. The molecular weight of the purified enzyme was estimated by gel filtration with Sephadex G-200.

Examination of substrate specificity

Self-transfer of fructose moiety, Michaelis constants and molecular activities. In each case, the level of the enzyme was regulated so that not more than $10 \%$ of the substrate was transformed in the course of incubation. The selftransfer reaction was done using an enzyme mixture $(1.0 \mathrm{ml})$ containing $10 \%$ of each substrate in a $40 \mathrm{~mm}$ McIlvaine buffer, pH 5.0. After incubation for $1 \mathrm{hr}$ at $40^{\circ} \mathrm{C}$ the transferred products were analyzed by HPLC. Then, similar incubations were done for the substrates which gave transferred products with the exception that eight different substrate concentrations $(0.05 \sim 1.5 \mathrm{M})$ were used. A Lineweaver-Burk plotting of the resulting data obtained by HPLC analysis gave each $K m$ value and molecular activity $\left(V_{\text {max }} / e_{0}\right)$ for the self-transfer reaction.

Fructosyl transfer from sucrose to several acceptors. This reaction was done using an enzyme solution ( $1 \mathrm{U}, \mathrm{I} \mathrm{ml}$ ) containing sucrose $(10 \%)$ and acceptor $(10 \%)$ in $40 \mathrm{~mm}$

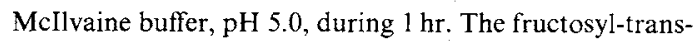
ferred products from sucrose to acceptor were investigated by analyzing the reaction mixture at 20 min intervals by HPLC or TLC and comparing them to their authentic samples.

\section{Results}

\section{Purification of the enzyme}

All of the operations for enzyme purification were done at $1 \sim 6^{\circ} \mathrm{C}$, and centrifugation was conducted at $6000 \times g$ for $15 \mathrm{~min}$. The enzyme solutions were concentrated by a Hollow Fiber System (model DC4 equipped with H1P 10-20: Amicon Corporation).

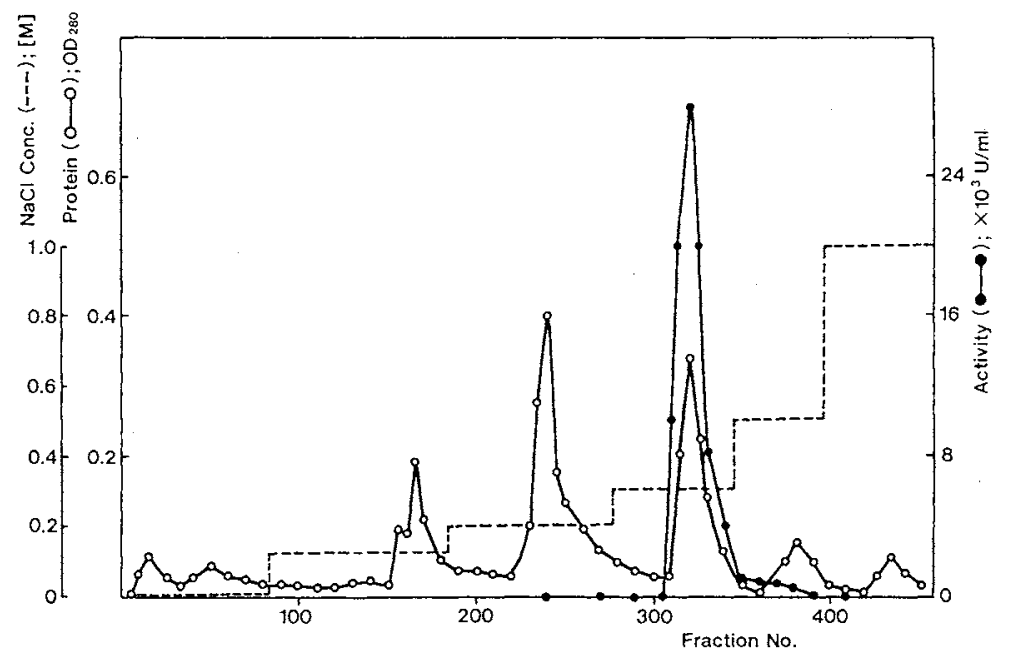

Fig. 1. DEAE-Sephadex A-50 Column Chromatograph of the Crude Extract from A. niger ATCC 20611.

The crude extract was put onto a DEAE-Sephadex A-50 column $(5.0 \times 35 \mathrm{~cm})$ equilibrated with $20 \mathrm{~mm}$ phosphate buffer, $\mathrm{pH} 6.0$. A step-wise elution was done with $0 \mathrm{M}, 0.15 \mathrm{M}, 0.2 \mathrm{M}, 0.3 \mathrm{M}, 0.5 \mathrm{M}$ and $1.0 \mathrm{M} \mathrm{NaCl}$ in $20 \mathrm{~mm}$ phosphate buffer, as indicated by the dotted line. Ten-ml fractions of eluent were collected at a flow rate of $120 \mathrm{ml}$ per $\mathrm{hr}$. - , transfructosylating activity; $\bigcirc-\mathrm{O}$, absorbance at $280 \mathrm{~nm} ;-\cdot---, \quad \mathrm{NaCl}$ concentration. 
1) Calcium acetate and ammonium sulfate fractionation. Solid calcium acetate was added to the crude extract $(3.41)$ to $6 \%$ saturation. After standing overnight, the solution was centrifuged to remove the precipitates and the supernatant $(3.41)$ was condensed to about one-fifth by ultrafiltration. Solid ammonium sulfate to $75 \%$ saturation was added to the condensate, and the resulting solution was left

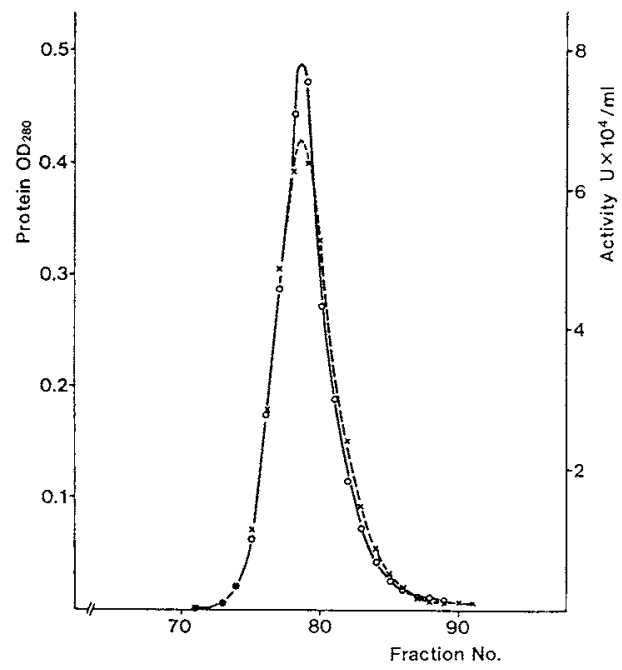

Fig. 2. Sepharose 6B Re-chromatography of "Sepharose 6B (1st) Conc." Fraction.

"The 1st conc." fraction was put onto a Sepharose 6B column $(5.0 \times 62 \mathrm{~cm})$ equilibrated with a $20 \mathrm{~mm}$ phosphate buffer ( $\mathrm{pH}$ 6.0) containing $100 \mathrm{~mm} \mathrm{NaCl}$, and eluted with the same buffer. Eluates were collected in $9.8-\mathrm{ml}$ fractions. $\bigcirc-O$, transfructosylating activity; $\times \cdots \times$, absorbance at $280 \mathrm{~nm}$. overnight. The supernatant separated by centrifugation was concentrated again to about one-tenth by ultrafiltration.

2) DEAE-Sephadex column chromatography. The protein was eluted from the DEAESephadex column with a stepwise $\mathrm{NaCl}$ concentration and transfructosylating activity was detected in 0.5-l fractions (No. $308 \sim 358$ ) (Fig. 1). The active fractions were combined and concentrated by ultrafiltration to give a "DEAE-Sephadex conc." fraction.

3) Sepharose $6 B$ column chromatography. The "DEAE-Sephadex conc." fraction was further purified by gel filtration on Sepharose $6 \mathrm{~B}$ column. Rechromatography of the active fractions showed a single symmetrical peak (Fig. 2). The active fractions No. $74 \sim 83$ were combined, concentrated and dialyzed overnight against a $10 \mathrm{~mm}$ phosphate buffer, $\mathrm{pH}$ 6.0 , to give a "Sepharose $6 \mathrm{~B}$ ( $2 \mathrm{nd}$ ) conc." fraction, the final purified $\beta$-fructofuranosidase. The purification process of the enzyme is summarized in Table I. The enzyme was purified approximately 52 -fold with a $10 \%$ yield reçovery from the crude extract. The purified enzyme was homogenous by SDS-PAGE and chromatofocusing (Fig. 3).

\section{Properties of $\beta$-fructofuranosidase}

1) Molecular weight. As shown in Fig. 4, the molecular weight of the enzyme was estimated to be 340,000 from gel filtration with Sephadex G-200. In SDS-PAGE analysis the

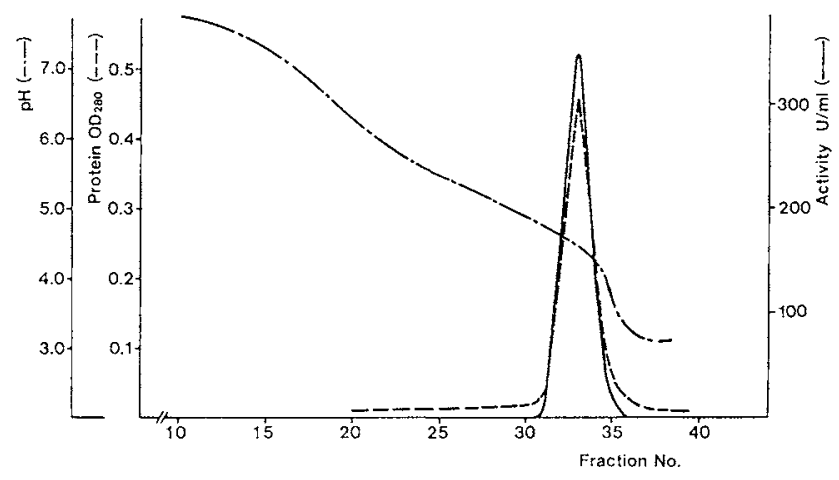

Fig. 3. Chromatofocusing of the Purified Enzyme on PBE 94.

$\longrightarrow$, transfructosylating activity; ----, protein at $280 \mathrm{~nm} ;-.-, \mathrm{pH}$. 
Table I. Purification of $\beta$-Fructofuranosidase from $A$. niger. ATCC 20611

\begin{tabular}{|c|c|c|c|c|c|}
\hline Step & $\begin{array}{l}\text { Volume } \\
\text { (ml) }\end{array}$ & $\begin{array}{l}\text { Total } \\
\text { activity } \\
\text { (U) }\end{array}$ & $\begin{array}{l}\text { Total } \\
\text { protein } \\
\text { (mg) }\end{array}$ & $\begin{array}{c}\text { Specific } \\
\text { activity } \\
\text { (U/mg protein) }\end{array}$ & $\begin{array}{c}\text { Recovery } \\
(\%)\end{array}$ \\
\hline Crude extract & 3400 & $36.9 \times 10^{4}$ & 6770 & 54.5 & 100 \\
\hline \multirow{2}{*}{$\mathrm{Ca}(\mathrm{OAc})_{2}(6 \%) \begin{array}{l}\text { sup. } \\
\text { conc. }\end{array}$} & 3400 & - & - & - & - \\
\hline & 725 & $19.2 \times 10^{4}$ & 1430 & 135 & 52 \\
\hline \multirow{2}{*}{$(\mathrm{NH})_{2} \mathrm{SO}_{4}(75 \%)$ sup. } & 880 & $16.6 \times 10^{4}$ & 739 & 225 & 45 \\
\hline & 80 & $16.4 \times 10^{4}$ & 198 & 828 & 44 \\
\hline DEAE-Sephadex conc. & 8.0 & $9.27 \times 10^{4}$ & 47.7 & 1940 & 25 \\
\hline Sepharose $6 \mathrm{~B}$ (1st) conc. & 11.1 & $4.93 \times 10^{4}$ & 19.0 & 2600 & 13 \\
\hline Sepharose $6 \mathrm{~B}(2 \mathrm{nd})$ conc. & 8.6 & $3.85 \times 10^{4}$ & 13.7 & 2810 & 10 \\
\hline
\end{tabular}

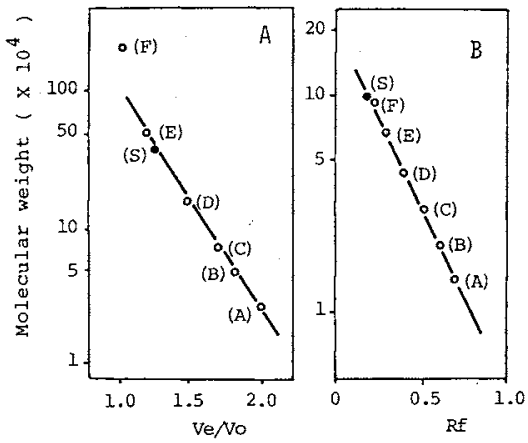

Fig. 4. Estimation of Molecular Weight of the Purified Enzyme by Gel Filtration [A] and SDS-PAGE [B].

A: Gel filtration on Sephadex G-200. Column size, $1.6 \times 95 \mathrm{~cm}$; eluent, $20 \mathrm{~mm}$ phosphate buffer. $(\mathrm{pH}$ $6.0)+0.1 \mathrm{M} \mathrm{NaCl}$; flow rate, $4.5 \mathrm{ml} / \mathrm{hr}$; temp., $5^{\circ} \mathrm{C}$; protein, $50 \sim 100 \mu \mathrm{g}$ each; detector, UV $(280 \mathrm{~nm})$; fraction, $0.75 \mathrm{ml} /$ tube. Standard proteins: (A), chimotripsinogen $(25,000)$; (B), hen egg albumin $(45,000)$; (C), bovine serum albumin $(67,000)$; (D), aldolase $(158,000)$; (E), ferritin $(450,000)$; (F), blue dextran $(2,000,000)$; (S), purified enzyme.

B: SDS-PAGE. Standard proteins: (A), $\alpha$-lactalbumin $(14,400)$; (B), tripsin inhibitor $(20,100) ;(C)$, anhydrase $(30,000)$; (D), ovalbumin $(43,000)$; (E), albumin $(67,000)$; (F), phospholylase $(94,000)$; (S), purified enzyme.

enzyme gave a single protein band, which was estimated to be of molecular weight 100,000 .

2) Carbohydrate content. The carbohydrate content of the enzyme was found to be $20 \%$ (carbohydrate/protein, $w / w$ ) by the phenol-sulfuric acid method.

3) Effects of $p H$. The activity of the purified enzyme and cells of $A$. niger were measured at various $\mathrm{pHs}$ from 3.0 to 11.0 (Fig. $5 \mathrm{~A})$. The optimal $\mathrm{pH}$ was $\mathrm{pH} 5.0 \sim 6.0$. The purified enzyme had almost no activity under
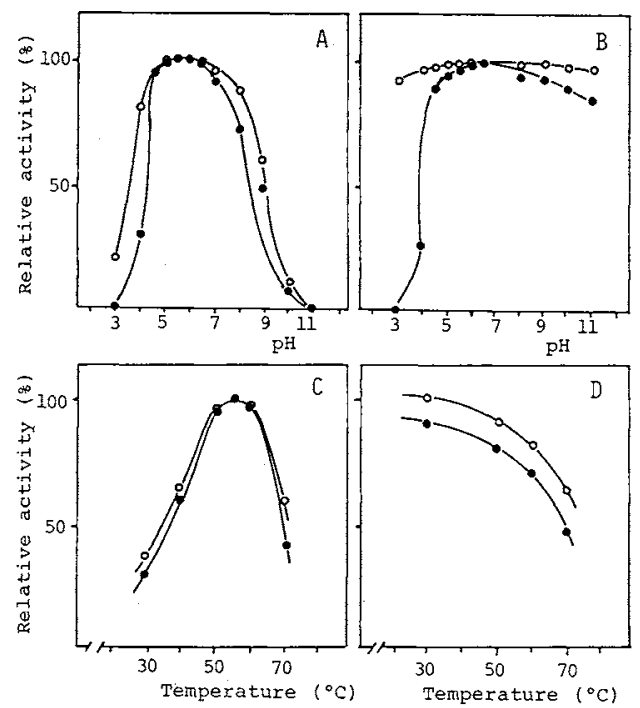

Fig. 5. Effects of $\mathrm{pH}$ and Temperature on the Transfructosylating Activity and Stability.

A: $\mathrm{pH}$-activity. The reaction mixtures containing $2.5 \mathrm{ml}$ of $10 \%$ sucrose solution $(0.8 \mathrm{unit})$ were incubated for $1 \mathrm{hr}$ at $40^{\circ} \mathrm{C}$ and at various $\mathrm{pHs}$.

B: pH-stability. The enzyme solutions $(12 \mathrm{U}, 0.5 \mathrm{ml})$ were incubated for $30 \mathrm{~min}$ at $40^{\circ} \mathrm{C}$ in an appropriate buffer $(0.5 \mathrm{ml})$, and adjusted to $\mathrm{pH} 5.0$ by adding $0.25 \mathrm{M}$ McIlvaine buffer $(5 \mathrm{ml})$. Then the enzyme activities were assayed by the standard method.

$\mathrm{C}$ : Temperature-activity. The reaction mixture containing $2.5 \mathrm{ml}$ of $10 \%$ sucrose solution ( 0.8 unit) were incubated at various temperatures for $1 \mathrm{hr}$ at $\mathrm{pH}$ 5.0.

D: Temperature stability. After the enzyme was incubated in a $0.1 \mathrm{M} \mathrm{McIlvaine} \mathrm{buffer,} \mathrm{pH} 5.0$, at various temperatures for $30 \mathrm{~min}$, the remaining activities were assayed by the standard method. Initial activities before incubation were expressed as $100 \%$ (purified enzyme, $0.78 \mathrm{U} / \mathrm{ml}$; cells, $0.81 \mathrm{U} / \mathrm{ml}$ ).

The buffers used were as follows: $\mathrm{pH} 3.0$ to $8.0,0.1 \mathrm{M}$ Mcllvaine buffer; $\mathrm{pH} 8.0$ to 11.0, Kolthoff buffer. purified enzyme; $\bigcirc-\mathrm{O}$, cells of $A$. niger. 
$\mathrm{pH} 3.0$ and above $\mathrm{pH}$ 10.0. The two samples were incubated for an examination of $\mathrm{pH}$ stability at various $\mathrm{pH}$ values for $30 \mathrm{~min}$ at $40^{\circ} \mathrm{C}$, and then the remaining activity was assayed. The purified enzyme was stable at $\mathrm{pH}$ $4.5 \sim 10.0$, but the enzyme in $A$. niger cells was stable from pH 3.0 to 11.0 (Fig. 5B).

4) Effects of Temperature. The activity of the purified enzyme was measured at various temperatures from 30 to $70^{\circ} \mathrm{C}$. The optimal temperature was $50 \sim 60^{\circ} \mathrm{C}$ (Fig. $5 \mathrm{C}$ ). The ef-

Table II. EfFects of CHEMICALS ON THE TranSFructosylating ACTIVITY

\begin{tabular}{|c|c|c|}
\hline Compound & Concentration & $\begin{array}{c}\text { Relative activity } \\
(\%)\end{array}$ \\
\hline \multirow[t]{2}{*}{$\mathrm{HgCl}_{2}$} & $0.1 \times 10^{-3} \mathrm{M}$ & 15 \\
\hline & $0.01 \times 10^{-3} \mathrm{M}$ & 75 \\
\hline $\mathrm{AgNO}_{3}$ & $1.0 \times 10^{-3} \mathrm{M}$ & 86 \\
\hline $\mathrm{MnSO}_{4}$ & $1.0 \times 10^{-3} \mathrm{M}$ & 88 \\
\hline $\mathrm{CuSO}_{4}$ & $1.0 \times 10^{-3} \mathrm{M}$ & 93 \\
\hline $\mathrm{CoCl}_{2}$ & $1.0 \times 10^{-3} \mathrm{M}$ & 96 \\
\hline $\mathrm{ZnSO}_{4}$ & $1.0 \times 10^{-3} \mathrm{M}$ & 96 \\
\hline $\mathrm{MgSO}_{4}$ & $1.0 \times 10^{-3} \mathrm{M}$ & 98 \\
\hline $\mathrm{Pb}(\mathrm{OAc})_{2}$ & $1.0 \times 10^{-3} \mathrm{M}$ & 100 \\
\hline $\mathrm{AlCl}_{3}$ & $1.0 \times 10^{-3} \mathrm{M}$ & 95 \\
\hline $\mathrm{FeCl}_{3}$ & $1.0 \times 10^{-3} \mathrm{M}$ & 100 \\
\hline PCMB & $0.1 \times 10^{-3} \mathrm{M}$ & 110 \\
\hline EDTA & $1.0 \times 10^{-3} \mathrm{M}$ & 97 \\
\hline Aniline & $1.0 \times 10^{-3} \mathrm{M}$ & 110 \\
\hline Oligostatin & $0.5 \mathrm{mg} / \mathrm{ml}$ & 110 \\
\hline Nojirimycin & $0.5 \mathrm{mg} / \mathrm{ml}$ & 100 \\
\hline Control $\left(\mathrm{H}_{2} \mathrm{O}\right)$ & - & 100 \\
\hline
\end{tabular}

A mixture of enzyme solution $(0.8 \mathrm{U}, 0.5 \mathrm{ml})$, sucrose solution $(26 \% \mathrm{w} / \mathrm{v}, 1.0 \mathrm{ml})$ and $0.1 \mathrm{M} \mathrm{McIlvaine} \mathrm{buffer}(\mathrm{pH}$ 5.0) $(1.0 \mathrm{ml})$ was incubated for $1 \mathrm{hr}$ at $40^{\circ} \mathrm{C}$ in the presence of water or reagent solution $(0.1 \mathrm{ml})$, and the activities were assayed. fects of temperature on the stability of the enzyme and cells of $A$. niger were studied by keeping them at various temperatures for 30 min at $\mathrm{pH} 5.0$, and the remaining activities were then measured. As shown in Fig. 5D, the purified enzyme and the cells both remained above $81 \%$ of their initial activities up to $50^{\circ} \mathrm{C}$ and $60^{\circ} \mathrm{C}$, respectively.

5) Effects of chemicals. The effects of metal ions and some other organic chemicals on the purified enzyme was investigated and the results are shown in Table II. Only $\mathrm{Hg}^{2+}$ inhibited the activity of the enzyme.

6) Effects of sucrose concentration on the products. The effects of sucrose concentrations on the reaction products were successively studied by monitorring the changes of the carbohydrate composition in three different sucrose concentrations over $80 \mathrm{hr}$. Three units of each enzyme per gram sucrose were used in both reactions of $5.0 \%$ and $50 \%$ of sucrose, but an excess $500 \mathrm{U}$ per gram sucrose was added to $0.5 \%$ of sucrose to investigate the final products of the enzyme reaction. As shown in Fig. 6, the total amounts fructooligosaccharides increased to $50 \%$ and $60 \%$ of the carbohydrate composition after $24 \mathrm{hr}$ of incubation of $5.0 \%$ and $50 \%$ sucrose solutions, respectively, and then those decreased with an increase of fructose. Treatment of excess enzyme with $0.5 \%$ of sucrose solution gave both $50 \%$ of glucose and fructose as the final products. At the early stage $(2 \mathrm{hr})$ some fructooligosaccharides ( ca. 25\%) were formed, but they were hydrolyzed over $10 \mathrm{hr}$ into glucose
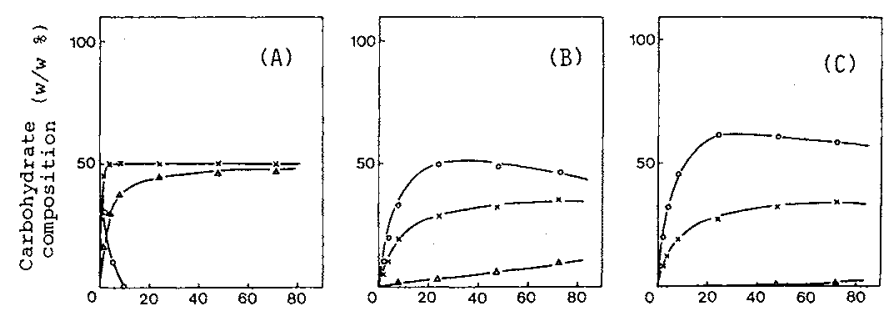

reaction time (hr)

Fig. 6. Effects of Sucrose Concentrations on the Reaction Products.

Enzyme reactions were done at $40^{\circ} \mathrm{C}$ in McIlvaine buffer, $\mathrm{pH} \mathrm{5.0,} \mathrm{under} \mathrm{the} \mathrm{following} \mathrm{conditions.} \mathrm{Sucrose}$ concentration and the enzyme used per g sucrose: (A), $0.5 \%$ and $500 \mathrm{U} ;(\mathrm{B}), 5.0 \%$ and $3 \mathrm{U} ;(\mathrm{C}), 50 \%$ and $3 \mathrm{U}$. $\bigcirc-O$, total fructooligosaccharides; $\triangle-\triangle$, fructose; $\times-\times$, glucose. 
and fructose.

\section{Substrate specificity}

1) Self-transfer of fructoses moiety, $\mathrm{Mi}$ chaelis constants $(\mathrm{Km})$ and molecular activities $\left(V_{\max } / e_{0}\right)$ for several substrates. The term "selftransfer of fructose moiety" is used when a substrate acts as both fructosyl donor and acceptor. The transfer was investigated by

Table III. Self-transfer of Fructose Moiety, Michaelis Constants and Molecular Activities

\begin{tabular}{|c|c|c|c|}
\hline Substrate & Product & $K m(\mathrm{M})$ & $\begin{array}{l}\text { Relative } \\
V_{\max } / e_{0}\end{array}$ \\
\hline Sucrose (GF) & $\mathrm{GF}_{2}$ & 0.29 & 100 \\
\hline 1-Kestose $\left(G_{2}\right)$ & $\mathrm{GF}_{3}$ & 0.80 & 52 \\
\hline Nystose $\left(\mathrm{GF}_{3}\right)$ & $\mathrm{GF}_{4}$ & 0.14 & 0.01 \\
\hline $1^{F_{-}}$Fructosyl-GF ${ }_{3}\left(G_{4}\right)$ & $\mathrm{GF}_{5}$ & 0.37 & 0.01 \\
\hline Raffinose & Raf-F & 0.20 & 0.02 \\
\hline Inulobiose $\left(\mathrm{F}_{2}\right)$ & $\mathrm{F}_{3}$ & $*$ & $*$ \\
\hline Turanose & None & - & - \\
\hline Isomalturose & Noné & - & - \\
\hline Melezitose & None & - & - \\
\hline
\end{tabular}

* Not tested.

Table IV. Fructosyl Transfer from Sucrose to Several Acceptors

\begin{tabular}{|c|c|c|}
\hline \multicolumn{2}{|c|}{ Acceptor } & \multirow{2}{*}{$\begin{array}{l}\text { Fructose } \\
\text { transferred }^{a}\end{array}$} \\
\hline Type & Substrate & \\
\hline \multirow[t]{4}{*}{$\mathrm{Gl}-(2 \mathrm{~F} 1)_{n}-2 \mathrm{~F}$} & None & $(+)^{b}$ \\
\hline & 1-Kestose & + \\
\hline & Nystose & + \\
\hline & $1^{\mathrm{F}}-\mathrm{F}-\mathrm{Nystose}$ & + \\
\hline \multirow[t]{2}{*}{$\mathrm{Fl}-(2 \mathrm{~F} 1)_{n}-2 \mathrm{~F}$} & Inulobiose & + \\
\hline & Inulotriose & + \\
\hline \multirow[t]{2}{*}{ Galn-G1-2F } & Raffinose & + \\
\hline & Stachyose & + \\
\hline \multirow[t]{2}{*}{$\mathrm{R}-\mathrm{OH}$} & Fructose $(\mathrm{F})$ & + \\
\hline & $\mathrm{MeOH}, \mathrm{EtOH}$ & + \\
\hline \multirow[t]{7}{*}{ Others } & Glucose $(\mathrm{G})$ & - \\
\hline & Galactose (Gal) & - \\
\hline & Turanose (G1-3F) & - \\
\hline & Malturose (G1-4F) & - \\
\hline & Isomaiturose $(\mathrm{G} 1-6 \mathrm{~F})$ & - \\
\hline & Maltose $(G 1-4 G)$ & - \\
\hline & Melezitose (G-F3-1G) & - \\
\hline
\end{tabular}

a The symbols + indicate the presence of the transferred products.

$b$ Self-transferred product (1-kestose) of sucrose. incubating each substrate shown in Table III with the purified enzyme followed by a HPLC analysis of the product. The enzyme catalyzed fructosyl transfer to produce the transferred products from the substrates having terminal $2-\beta$-D-fructofuranose moiety such as sucrose, 1 -kestose, nystose, $1^{F}$-fructofuranosylnylstose and inulobiose, but failed to cleave turanose, isomalturose and melezitose. Furthermore, the effect of substrate concentration on the selftransfer reaction was studied. The enzyme reaction of each substrate done in eight different concentrations and $K m$ and relative $V_{\text {max }} / e_{0}$ were calculated from the results. As shown in Table III, sucrose had the largest $V_{\max } / e_{0}$ of the five substrates studied.

2) Fructosyl transfer from sucrose to several acceptors. An enzyme reaction of each $10 \%(\mathrm{w} / \mathrm{v})$ solution of sucrose and acceptor elucidated the properties of the structures as the fructosyl acceptor. The results showed that the purified enzyme catalyzed the fructosyl transfer from sucrose to terminal $2-\beta$-fructofuranosides, fructose and lower primary alcohols such as methanol and ethanol (Table IV).

\section{Discussion}

A fructooligosaccharide-producing enzyme purified from cells of $A$. niger was a glycoprotein having $20 \%(\mathrm{w} / \mathrm{w})$ carbohydrates, and its molecular weight was estimated by gel filtration to be 340,000 . On the other hand, the value obtained by SDS-PAGE was about onethird of the above value, 100,000 . This differnce suggested the presence of subunit structures in the enzyme, like those reported for Neurospora and Fusarium invertase. ${ }^{5,6)}$ As no inhibition of the purified enzyme was observed with EDTA, it seems that metals are not essential for the transfer action of the enzyme. An interesting property was found in the effects of sucrose concentration on the products. As shown in Fig. 6, the enzyme reaction in $50 \%$ sucrose solution yielded the transferred products almost exclusively accompanied by glucose as the by-product, as if the enzyme was 
$\beta$-fructosyltransferase, though a small amount of fructose was produced by a prolonged reaction. On the other hand, the reaction with dilute substrate afforded fructose in addition to the transferred products only at an early stage, and finally gave a mixture of completely hydrolyzed products, glucose and fructose. It is well known that some $\beta$-fructofranosidases catalyze fructosyl transfer to produce oligosaccharides and their amounts increase with an increase in the substrate concentration. ${ }^{7.8)}$ These results support the hyothesis that the $A$. niger enzyme is a $\beta$-fructofranosidase having a strong fructosyl transfer activity, like Claviceps enzyme $^{9)}$ which produced neokestose from sucrose as the main products. Another property of the enzyme was observed in the substrate specificity including regiospecificity in the transfer site of fructosyl moiety. As shown in Tables III and IV, the purified enzyme transferred fructosyl moiety to terminal 2- $\beta$-fructofuranosides with the exception of fructose and lower primary alcohols. Furthermore, the moiety was solely transferred to the $1-\mathrm{OH}$ group of the terminal fructofuranosides. It was reported that $\beta$-fructofranosidase from yeast ${ }^{10)}$ and Claviceps purpurea $^{9)}$ had three acceptor groups (6-OH of glucoside, and $1-\mathrm{OH}$ and $6-\mathrm{OH}$ of furanoside) and two (6-OH of glucoside and 1-OH of furanoside) on sucrose, respectively. In comparison with these data, the $A$. niger enzyme has a higher regiospecificity in the fructosyl transfer reaction. The value of apparent $\mathrm{Km}$ of the purified enzyme for sucrose was $0.29 \mathrm{M}$, which seemed to be larger than those of hydrolytic $\beta$-fructofranosidase, for example, $0.0061 \mathrm{M}$ of $N$. crassa $^{5)} 0.0044 \mathrm{M}$ of $F$. oxysporium ${ }^{6)}$ and 0.025 $\mathrm{M}$ of Saccharomyces cerevisiae. ${ }^{11)}$ However, compared with the values for enzymes having fructosyl transfer activity, the $K m$ value of $A$. niger enzyme was not significantly different from those of $C$. purpurea enzyme $(0.148 \mathrm{M})$ and $\operatorname{SST}(0.11 \mathrm{M})$ of asparagus. ${ }^{12)}$

\section{References}

1) H. Hidaka, M. Hirayama and N. Sumi, Agric. Biol. Chem., 52, 1181 (1988).

2) A. G. Dickerson and J. Moor, Carbohydr. Res., 39, 162 (1972)

3) O. H. Lowry, N. J. Rosebrough, A. L. Farr and R. J. Randall, J. Biol. Chem., 193, 265 (1951).

4) M. Dubois, K. A. Gilles, J. K. Hamilton, P. A. Rebers and F. Smith, Anal. Chem., 28, 350 (1956).

5) R. L. Metzenberg, Biochim. Biophys. Acta, 89, 291 (1964).

6) M. Nishizawa, Y. Maruyama, and M. Nakamura, Agric. Biol. Chem., 44, 489 (1980).

7) J. Edelman, in "Advances in Enzymology," Vol. 17, ed. by F. F. Nord, Interscience Publishers, Inc., New York, 1956, pp. $189 \sim 232$.

8) H. Hidaka and M. Hirayama, Kagaku to Seibutsu, 23, 600 (1985).

9) A. G. Dickerson, Biochem. J., 129, 263 (1972).

10) E. H. Fischer, L. Kothes and J. Felling, Helv. Chim. Acta, 34, 1134 (1951).

11) G. Gascoń, N. P. Neumann and J. O. Lampen, $J$. Biol. Chem., 243, 1578 (1968).

12) N. Shiomi and M. Izawa, Agric. Biol. Chem., 44, 603 (1980). 